\title{
Dunes of the Toruń Basin against palaeogeographical conditions of the Late Glacial and Holocene
}

\author{
Leon Andrzejewski, Piotr Weckwerth
}

\author{
Department of Geomorphology and Palaeogeography of Quaternary, Institute of Geography, \\ Faculty of Biology and Earth Sciences, Nicolaus Copernicus University, \\ Gagarina 9, 87-100 Toruń, e-mail: pweck@umk.pl
}

\begin{abstract}
Dunes are generally found in Poland either along the seacoast or inland, mainly in river valleys and on glaciofluvial outwash fans. The position of the dune fields of the Torun Basin is unique also due to the fact that it is dominated by large dune forms, while the western part of the European sand belt is dominated by aeolian coversands. Dunes in the Torun Basin are found on all terraces and make up vast clusters (complexes). W. Mrózek (1958) delimited there six dune fields. The dunes located in the Torun Basin take the shape of crescent (parabolic) forms, simple ramparts (longitudinal and transversal) and irregular hilly forms. Additionally, there are numerous vast and plain areas covered with aeolian sand up to 4-5 m deep, which contain scattered irregular low dunes. The dunes of the Torun Basin are mainly built of fine-grained and medium-grained sands which come from the local substratum of fluvioglacial and river deposits. The results of the studies on aeolian deposits carried out in the in Europe indicate that the earliest aeolian series (Older Coversand I, van der Hammen 1971) were deposited as early as Late Pleniglacial. In Poland this series has not been recognized, although the river deposits of that age have a larger content of quartz grain abraded in aeolian environment (Kozarski 1990; Manikowska 1991; Goździk 1991). New research claims in the Torun Basin that the dunes formed chifly in the Younger Dryas, but probably also in the Older Dryas and even in the Preboreal.
\end{abstract}

Key words: inland dunes, aeolian cover sands, European sand belt, aeolian processes, dune-forming phase Toruń Basin.

\section{Introduction}

Aeolian forms are characteristic to lowland Europe (Fig. 1). They include both accumulative forms, such as dunes and aeolian cover sands, and erosive forms, such as deflation depressions and pavements. Dunes developed as a result of sand being deposited by wind and at the presence of vegetation in dry climate at the end of Weichselian and in Holocene. Common inland dune types include alluvial-derived dunes, which are formed of windblown sands of river or spillway terraces or of deluvial deposits, and fluvial-derived dunes, which developed periodically on floodplains, deltas and glaciofluvial outwash fans.

Geomorphological research of dunes conducted so far has aimed at classifying morphogenetic types of dunes, es- tablishing their age (dune-forming phases) and reconstructing the wind directions and its velocities. Both morphologic and morphometric classifications of dunes are based on dune shapes and sizes and their relation to dune-forming wind directions. The main morphological, structural and textural features of dunes depend on aerodynamic conditions, including the changes in the wind direction, frequency and velocity. According to numerous authors, apart from climatic conditions other environmental factors play an important role, such as relief (for instance the course of the valley forms), lithology of the area, the depth of the water table and a type of vegetation (Wojtanowicz 1969, 1970; Borówka 1980). The most common classifications of inland dunes include simple and complex dunes. Simple dunes are either rampart dunes (longitudinal, transverse 


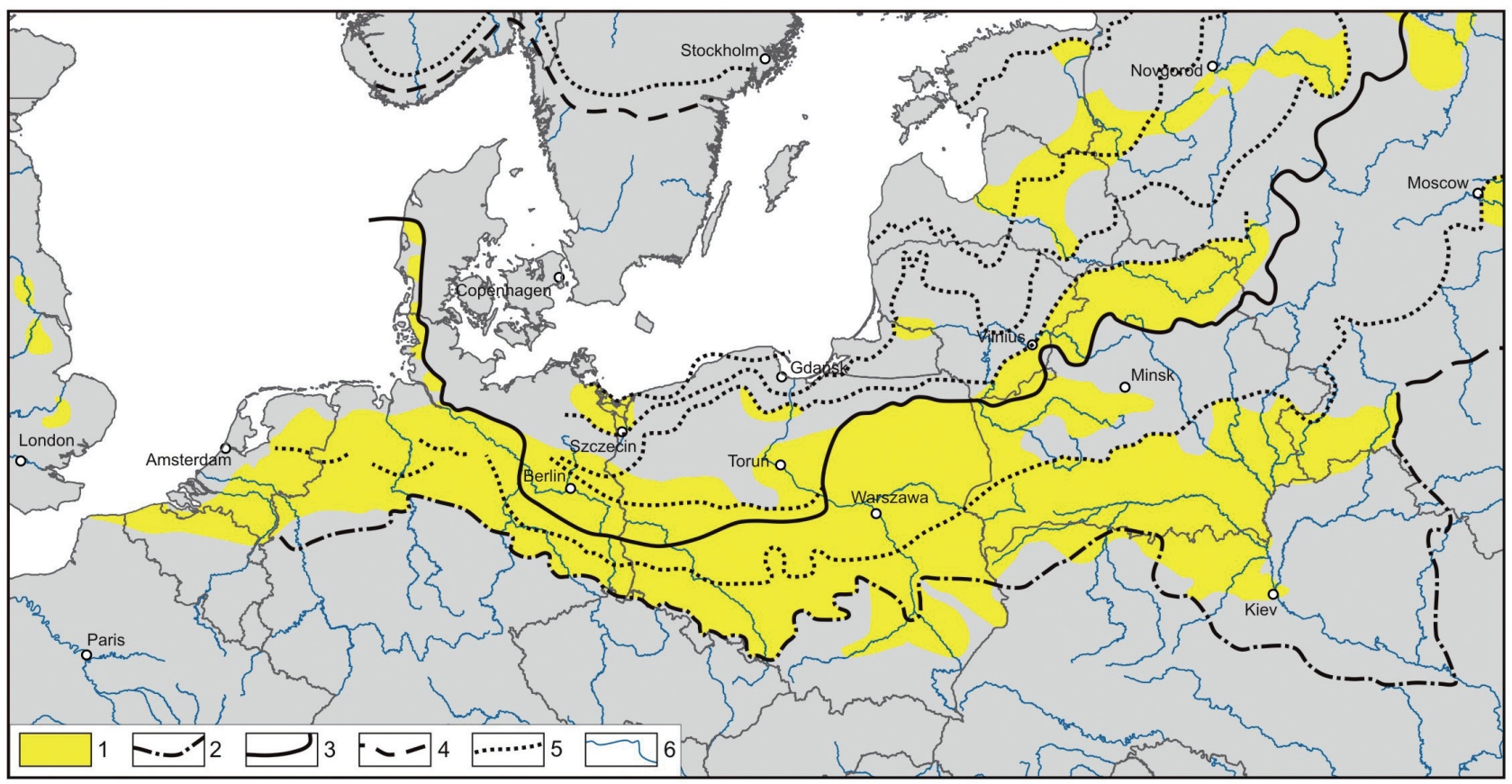

Figure 1. Location of the Torun Basin against the extent of the European sand belt (after Zeeberg 1998). 1 - sand belt 2, - saalian max ice marigin, 3 - weichselian max ice marigin, 4 - ice marigin in Younger Dryas, 5 - sub-stage ice extent, 6 - main rivers

and oblique) or bent dunes (crescent, shield, parabolic and barchan-like). Complex dunes, which originate through a merge (fusion) of other forms, take similar shapes or form complicated star or rampart-trellis forms (Wojtanowicz 1969).

In Poland dunes are generally found either along the seacoast or inland, mainly in river valleys and on glaciofluvial outwash fans. The largest dune complexes include the Warta-Noteć Inter-river, the Torun Basin, the Kampinos Primeval Forest and the Kurpie Primeval Forest. One of the main conditions for dune formation in dry climate is the presence of loose sand covers. Thus, in the Torun Basin dunes are found on all terraces. Locally, they are also found on the adjacent morainic plateaus (Fig. 2). Dunes of the Torun Basin make up vast clusters (complexes). W. Mrózek (1958) delimited there six dune fields. These are the following fields: the Bydgoszcz Dune Field between Lake Jezuickie, the valley of the Old Noteć and the city of Bydgoszcz; the Łabiszyn Dune Field between Brzoza, Łabiszyn and Smolniki; the Solec-Chrośna Dune Fidel between Solec Kujawski, Osiek Wielki, Nowa Wieś Wielka and Lake Jezuickie; the Toruń-AleksandrówGniewkowo Dune Field; the dune field between the Mień and the Drweca rivers; and the dune field between the Drwęca River and the Vistula gap at Fordon. The aeolian forms at the two latter locations, however, are often scattered over large areas.

\section{Review of the dune studies of the Toruń Basin}

First geomorphological research of the dune forms located in the Torun Basin was conducted at the beginning of the 20th century by S. Lencewicz (1922). He pointed at the relatively large area taken by this field in relation to the total area of Poland. Moreover, S. Lencewicz argued this dune field developed due to favourable geological and geomorphological conditions, and recorded the dominant type of dunes as being parabolic and the dominant wind direction responsible for their creation as being western. Similar views were represented by R. Galon (1958) and W. Mrózek (1958). Beside delimiting the above mentioned six dune fields in his vast morphometric and geomorphological analysis of the dunes in the Torun Basin, W. Mrózek gave a general characteristics of the geological structure of these dunes and described the dune-forming processes in relation to both geological and relief conditions. He described complex ellipsoidal dune forms, as well as tried to reconstruct the wind directions and to delimit the duneforming phases.

The issues of the development of dunes in the Torun Basin were also tackled in numerous papers on development of aeolian forms in Poland (Galon 1958; Krygowski 1961; Nowaczyk 1986). Dunes were the study issue when the relief of the Torun surroundings or of the Lower Vistula 


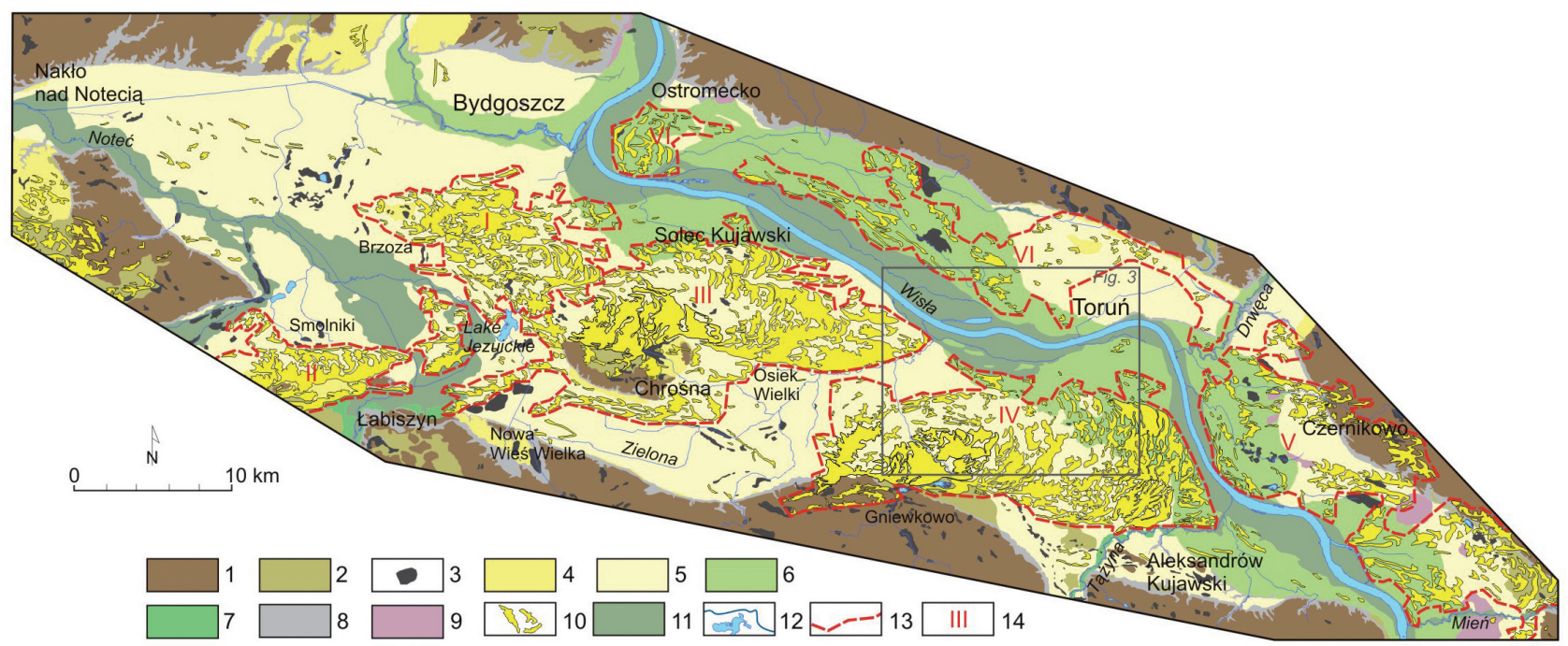

Figure 2. Dunes and dune fields in the Toruń Basin (after Weckwerth 2004). 1 - moraine plateau, 2 - outwash, 3 - kettles, 4 - terrace X, 5 - spillway (pradolina) terraces, 6 - terraces of Vistula, Brada and Drwęca rivers, 7 - terraces of another rivers, 8 - slopes and denudative forms, 9 - alluvial fans, 10 - dunes, 11 - flood plains, 12 - rivers and lakes, 13 - extent of the dune filds, 14 - numbering of dune filds (after Mrózek 1958)

Valley and its tributaries was analysed (Niewiarowski \& Tomczak 1969; Andrzejewski 1985, 1994; Niewiarowski \& Weckwerth 2006). Besides, the selected dune forms of the Torun Basin were studied in detail in terms of their geological structure and the reconstruction of aeolian processes (Okołowicz 1949, 1952; Churska 1969; Oczkowski et al. 2000; Jankowski \& Weckwerth 2000). One of the more important directions in aeolian studies refers to palaeopedological research, which enabled the scientists to delimit the dune-forming phases and periods in the Torun Basin (Jankowski 2000, 2003, 2007).

\section{General characteristics of the dunes of the Toruń Basin}

The dunes located in the Torun Basin take the shape of crescent (parabolic) forms, simple ramparts (longitudinal and transversal) and irregular hilly forms. Additionally, there are numerous vast and plain areas covered with aeolian sand up to 4-5 $\mathrm{m}$ deep, which contain scattered irregular low dunes. According to W. Mrózek (1958), the dunes of up to 3-9 m make up 31\% of the entire area of the Torun Basin, those 10-25 m high make up $65 \%$, while those over $25 \mathrm{~m}$ take up 3\% of this area. The highest dune of $44.7 \mathrm{~m}$ (115.9 $\mathrm{m}$ above sea level) is located in the Solec-Chrośno Dune Field (Fig. 2). In accordance with A. Załuska (2008), out of 335 dunes she studied in the Torun Basin about $38 \%$ is classified as longitudinal dunes, $28 \%$ as parabolic dunes, $22 \%$ as irregular dunes and $12 \%$ as transversal dunes. Domination of longitudinal dunes may be the outcome of transformation of parabolic dunes. Nearly half of all the dunes located in the Torun Basin are relatively small forms of up to $300 \mathrm{~m}$ in length (Załuska 2008).

Parabolic dunes in the Torun Basin are mainly U-shaped and V-shaped. They have prolonged arms up to $20-30 \mathrm{~m}$ in height and $100-400 \mathrm{~m}$ in width. Their height increases towards the front of the dune. The arms of the crescent forms in the Torun Basin are open towards the west, and the gradients of their windward slopes $\left(3^{\circ}-20^{\circ}\right)$ are lower than the gradients of their leeward slopes $\left(5^{\circ}-32^{\circ}\right)$. Irregularity of such forms is visible in the asymmetric development of the arms' length and their deflection. Moreover, in many places the arms of parabolic dunes join together to form elongated ramparts. It has been accepted that parabolic dunes form on the areas covered with scarce bushy vegetation and under the condition of ample input of sand material, and that their shape indicates the wind direction at the final period of the dune-forming process. In the Torun Basin these were generally the winds from the western directions (Mrózek 1958). A common phenomenon connected with parabolic dunes in the Torun Basin is the fact hat their arms join to form the 'cobra' type (Wojtanowicz 1969) or complex forms of joined parabolic dunes connected together in groups if elliptic shape (Mrózek 1958).

Longitudinal dunes of the Torun Basin are dominated by forms lower than the parabolic ones (a few metres high), although they can reach a few kilometres in length. Slopes of the longitudinal dunes are mainly symmetric, and their course might have been forced by the course of mor- 


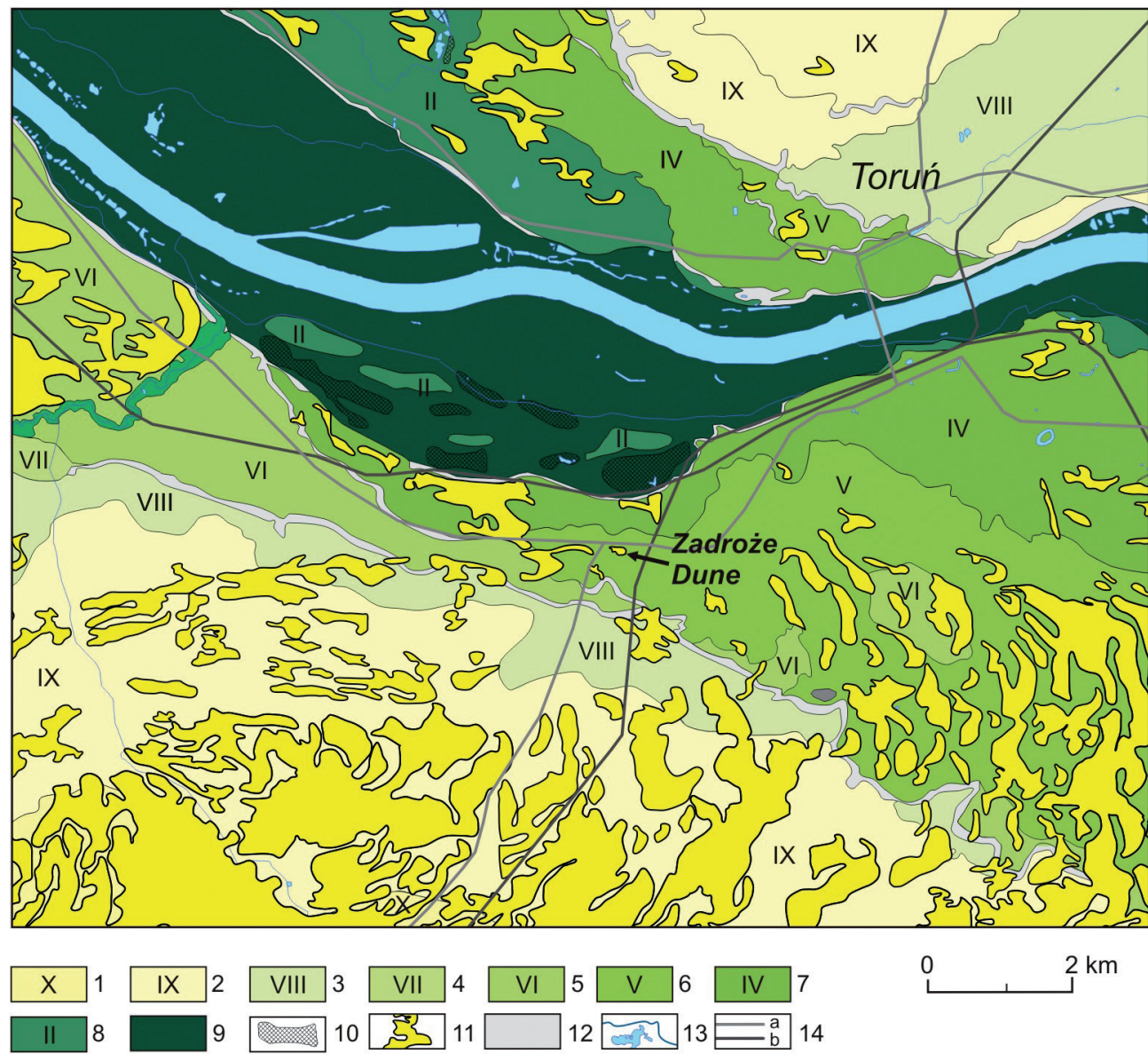

Figure 3. Relief of the central-eastern part of the Torun Basin in the surrounding of the dune Zadroże (after Weckwerth 2004). 1-5 Toruń-Eberswalde Pradolina terraces, 6-8 - Vistula river terraces (terraces numbering after Galon 1953, 1968), 9 - valley floor, 10 - peat, 11 - dunes, 12 - slopes, 13 - rivers and lakes, 14 - main roads (a) and railways (b)

phological edges of terraces and morainic plateaus or the existence of elongated waterlogged depressions. Rampart forms of uneven crest line are mainly found on lower terraces. Apart from the mentioned morphological conditions, the formation of longitudinal dunes might have resulted from breaking and destroying the fronts of parabolic dunes. In such a case the sides of rampart dunes show asymmetry. Morphology of the dune in Zadroże indicates it is a rampart form of relatively small size (Okołowicz 1949). The fact it has asymmetrical slopes proves it developed from a parabolic dune located on the Vistula's terrace V (Fig. 3).

Another type of dunes fund in the Torun Basin is transversal ramparts. These forms developed from transformed parabolic dunes the arms of which moved faster. Such conditions were found in the areas of vast and thick sand series of uniform grain composition, relatively shallow water table and favourable phytosociological features (Mrózek 1958; Wojtanowicz 1969). Transversal dunes show significant asymmetry of their slopes.
Irregular dunes are generally smaller. They take the shape of knolls or short ramparts scattered chaotically over the area. Some of them developed due to regular forms being blown away. These forms are often accompanied by aeolian covers.

In accordance with the studies of W. Mrózek (1958), the sizes of the dune complexes of the Torun Basin increase eastwards. Similarly, the heights of the individual forms also grow eastwardly. All this is due to the fact that the dune complexes join each other. Four dune fields from among those mentioned by W. Mrózek are located on the left-bank side of the basin. Here the dunes are mainly located on the spillway (pradolina) terraces (XI-VI) and on the terrace V. However, the best developed dunes are found on the terrace IX and on the transitional terrace. The geological structure of these terraces is dominated by sands which show the tendency to get finer towards the surface (Weckwerth 2004, $2005 \mathrm{a}, \mathrm{b})$. This favours dune-forming processes. In the two other dune fields located on the right-bank side of the basin, 
the dunes do not form compact complexes. The only exception is the field in the vicinity of Ostromecko to the east of Bydgoszcz. Longitudinal dunes dominate on the low-lying terraces of the Vistula ( $50 \%$ of all the forms), while transversal dunes are rare there. On the other hand, the latter are common on the higher terraces, mainly IX and X (40\% and $27 \%$ respectively), as well as in the near-edge zone of the morainic plateaus (Załuska 2008). Parabolic dunes have developed on all terraces of the Torun Basin, although over half of them are found between the terrace IX and the surrounding morainic plateaus (Załuska 2008).

The dunes of the Torun Basin are mainly built of finegrained and medium-grained sands which come from the local substratum of fluvioglacial and river deposits. Sands of grain size lower than $0.25 \mathrm{~mm}$ make up $53.9 \%$ of all deposits, those of grain size of $0.25-0.5 \mathrm{~mm}-42.3 \%$, while those of grain size over $0.5 \mathrm{~mm}$ make up only $3.8 \%$. The dune in Zadroże is built in about $47 \%$ of sand of the grain size $0.34-0.51 \mathrm{~mm}$, in $25 \%$ of sand of grain size $0.25-$ $0.34 \mathrm{~mm}$, while in about $18 \%$ of sands of the grain size lower than $0.25 \mathrm{~mm}$.

\section{Dunes of the Toruń Basin against aeolian processes in Europe}

Dunes located in Poland are the central part of the European sand belt, which stretches from Great Britain to the east border of Poland (Zeeberg 1998), or even to the basin of the Pechora River (Mangerud et al. 1999). To the east of the Polish borders the sand belt gets divided into two zones. The southern one stretches across Belarus and Ukraine, while the northern one stretches in the north-east direction (Fig. 1). Generally it is accepted that the northern border of the latter zone goes along the maximum range of the Late Weichselian Glaciation, even though the Torun Basin and the Warta-Notec Inter-river lie to the north of it in one of the largest European ice-marginal spillways called TorunEberswalde Pradolina. Moreover, the position of the dune fields of the Torun Basin is unique also due to the fact that it is dominated by large dune forms, while the western part of the European sand belt is dominated by aeolian coversands. It is the result of the increasing dryness and continentality of the climate towards east as well as of the fact that air circulation during the dune-forming processes differed from what Western Europe experienced (Majdanowski 1958; Böse 1991; Koster 2005). Another unique feature of the dunes of the Torun Basin is the fact that they are clusters which form large compact complexes of ellipsoidal shape and which include diverse morphological types of dunes (longitudinal, transversal and parabolic). Additionally, dunes from and at different dune-forming phases coexist in the Torun Basin on both the outwash and the Vistula terraces as well as on the higher levels of the Vistula floodplain (for instance in the Unisław Basin, Niewiarowski 1987). Most of these forms have been fixed by vegetation, although there are the areas of aeolian sands being contemporarily blown, such as the Torun's military ground.

The results of the studies on aeolian deposits (coversands and dune sands) carried out in the Netherlands and Germany indicate that the earliest aeolian series (Older Coversand I, van der Hammen 1971) were deposited as early as Late Pleniglacial, i.e. 25-14 thousand years ago (Kasse 1999). These deposits represent the fluvio-aeolian sedimentation characteristic for the environment of active braided rivers in arctic conditions (Good \& Bryant 1985), the age of which in Germany was established to be 18-20 ka (Kasse 1999). In Poland this series has not been recognized, although the river deposits of that age have a larger content of quartz grain abraded in aeolian environment (Kozarski 1990; Manikowska 1991; Goździk 1991). In terms of the Torun Basin sandy series of the outwash levels were deposited before the Pomeranian Phase (Weckwerth 2004, $2005 \mathrm{a}, \mathrm{b})$. This, together with the fact that aeolian processes were probably intensified at that time, might have resulted with a larger load of aeolian sand in the then rivers.

The next dune-forming phase in Europe (Older Coversand II, van der Hammen 1971) was the Late Pleniglacial and Early Late Glacial - Oldest Dryas (ca 14-12.5 ka). It is know from a few sites in Poland (Nowaczyk 1986), although not located in the Torun Basin. The fact that there were a few dune-forming phases in Older and Younger Dryas has been proved by the results of the geological, palaeopedological and palynological researches carried out in the Torun Basin. The main dune-forming phase was classified as the Younger Dryas (10.9-10.25 ka) on the basis of the studies of the Alleröd fossil soil in CzernikowoWitowąż (Churska 1969). However, B. Nowaczyk (1986) insists the main dune-forming phase was Older Dryas, which has been proved on the basis of the age of dunes in the surroundings of Lake Jezuickie. Besides, Alleröd origin of the fossil soil was concluded on the basis of the sites Katarzynka and Rudak in Torun (Jankowski 2000, 2003; Jankowski \& Weckwerth 2000). It is found on aeolian coversands from the Older Dryas. So far, no older fossil soil from Bölling has been fund in the Torun Basin. This does not mean, however, there were no earlier dune-forming phases here, as no chronostratigraphic studies have been carried out in the compound dune complexes. The main dune-forming phase in the Torun Basin, which lasted during the Younger Dryas and the beginning of the Pre-boreal, has been supported by the TL datings of the deposits from the Torun Hill located on the edge of the Kuiavian Plateau (Oczkowski et al. 2000). An important finding is establishing the leading northern sector as the one from which the wind blew during the dune-forming process. Moreover, dunes formed in the Younger Dryas are poorly developed (5-8 $\mathrm{m}$ high) and are located on lower levels (terrace II of 
the Vistula, Niewiarowski \& Noryśkiewicz 1983). According to M. Jankowski (2003), there is another climatically separate dune-forming phase of the Pre-boreal period. This idea has been concluded on the basis of numerous mentions of a short-time cooling phase in Pre-boreal found in German and Dutch research. As M. Jankowski suggests, during the Boreal and Atlantic periods the dunes stabilized. During the sub-Boreal and sub-Atlantic periods, however, a new stage of the dune-forming processes took place due to local human activity.

\section{References}

Andrzejewski L., 1985, Niektóre zagadnienia kształtowania się systemu fluwialnego w późnym glaciale i holoceniena podstawie wybranych dolnych odcinków dopływów dolnej Wisły [Some issues of the formation of the fluvial system in the Late Glacial and Holocene on the basis of selected Lower stretches of the lower Vistula tributaries], Przegl. Geogr. 57(4): 561-580.

Andrzejewski L., 1994, Ewolucja systemu fluwialnego doliny dolnej Wisły w późnym vistulianie i holocenie na podstawie wybranych dolin jej dopływów [Evolution of the fluvial system of the lower Vistula valley in the Late Vistulian and Holocene on the base of selected valley of its tributaries], Rozprawy UMK, Torun.

Borówka K. R., 1980, Współczesne procesy transportu i sedymentacji piasków eolicznych oraz ich uwarunkowania i skutki na obszarze wydm nadmorskich [Present-day transport and sedimentation processes of eolian sands: controlling the factors and resulting phenomena on a coastal dune area], Prace Komisji GeograficznoGeologicznej 20.

Böse M., 1991, Palaeoclimatic interpretation of frostwedge casts and aeolian sand deposits in the lowlands between Rhine and Vistula in the Upper Pleniglacial and Late Glacial, Zeitschrift für Geomorphologie, Supplementebände 90: 15-28.

Churska Z., 1969, Fazy rozwoju wydmy w CzernikowieWitowężu [Evolutionary phases of dune situated at Czernikowo-Witowąż], [in:] R. Galon (ed.) Procesy i formy wydmowe w Polsce [Dune processes and forms in Poland], Prace Geograficzne, IG PAN 75: 181-203.

Galon R., 1958, Z problematyki wydm śródlądowych w Polsce [Sur les dunes continentales en Pologne], [in:] R. Galon (ed.) Wydmy śródlądowe Polski, część pierwsza [Les dunes continentales en Pologne, premier partie], PWN, Warszawa: 13-31.

Good T.R. \& Bryant I.D., 1985, Fluvio-aeolian sedimentation - an ex ample from Banks Island, NWT, Canada, Geogr. Ann., Ser. A 67: 33-46.

Goździk J., 1991, Sedimentological record of aeolian processes from the upper Plenivistulian and the turn of
Pleni- and Upper Vistulian in Central Poland Zeitschrift für Geomorphologie, Supplmentband 90: 51-60.

Jankowski M., 2000, Chronologiczna i przestrzenna zmienność gleb na stanowisku archeologicznym Katarzynka (nr 242) w północnej części Kotliny Toruńskiej [The chronological and spatial varietes of soils at the archeological site Katarzynka (No 242) in the northern part of the Toruń Basin], Acta Universitatis Nicolai Copernici, Geografia 30: 97-114.

Jankowski M., 2003, Historia rozwoju pokrywy glebowej obszarów wydmowych Kotliny Toruńskiej [The story of development of soil cover of dune areas of the Torun Basin], PhD thesis, UMK, Torun.

Jankowski M., 2007, Chronologia procesów wydmotwórczych w Kotlinie Toruńskiej w świetle badań paleopedologicznych [Chronology of dune-forming processes in the Torun Basin in the light of paleopedological researches], Przegl. Geogr. 79(2): 251-269.

Jankowski M. \& Weckwerth P., 2000, Nowe dane dotyczące budowy i wieku wydm w Kotlinie Toruńskiej [The new data to refer the geological structure and age of dunes in the Toruń Basin], [in:] P. Molewski, W. Wysota (eds.) Dawne i współczesne systemy morfogenetyczne środkowej części Polski Północnej, V Zjazd Geomorfologów Polskich, Toruń 11-14 września 2000 r. [The former and contemporary morphogenetic systems of central part of the North Poland, V Congres of the Association of Polish Geomorphologists, Torun 11-14 September 2000], Wydawnictwo UMK, Toruń: 209-217.

Jankowski M. \& Weckwerth P., 2000, Nowe dane dotyczące budowy i wieku wydm w Kotlinie Toruńskiej, [in:] P. Molewski, W. Wysota(eds.) Dawnei współczesne systemy morfogenetyczne środkowej części Polski Północnej, V Zjazd Geomorfologów Polskich, Toruń 11-14 września 2000 r., Wydawnictwo UMK, Toruń: 209-217.

Kasse C., 1999, Late Pleniglacial and Late Glacial aeolian phases in The Netherlands, [in:] W. Schirmer (ed.) Dunes and fossil soils, GeoArchaeoRhein 3: 61-82.

Koster E.A., 2005, Aeolian environments, [in:] E.A. Koster (ed.) The physical Geography of Western Europe. Oxford Regional Environments, Oxford University Press, Oxford: 139-160.

Kozarski S., 1990, Pleni- and Late Vistulian Aeolian Phenomena in Poland: New Occurrences, Palaeoenvironmental and Stratigraphic Interpretations, Acta Geographica ac Geologica et Meteorologica Debrecina 26-27(1987/1988): 31-45.

Krygowski B., 1961, Geografia fizyczna Niziny Wielkopolskiej cz. 1, Geomorfologia [Physical geography of the Great Poland Lowland part I, Geomorphology], PTPN, Komitet Fizjograficzy, Poznań.

Lencewicz S., 1922, O wieku środkowego Powiśla [Sur l'âge bassin de la Vistule moyenne], Posiedz. Nauk. PIG 3: 21-24. 
Majdanowski S., 1958, Zagadnienia klimatyczne okresów wydmowych w świetle glacjalnych i postglacjalnych zmian ogólnej cyrkulacji atmosferyczne w środkowej Europie [Les problemes climatiques des pèriodes de dunes par rapport aux variations glaciaires et postglaciaires de la circulation atmosphèrique gènèrale dans l'Europe Centrale, [in:] R. Galon (ed.) Wydmy śródlądowe Polski, część pierwsza [Les dunes continentales en Pologne, premier partie], PWN, Warszawa: $33-51$.

Mangerud J., Svendsen J.I. \& Astakhov V.I., 1999, Age and extent of the Barents and Kara Sea ice sheets in Northern Russia, Boreas 28 (1): 46-80.

Manikowska B., 1991, Vistulan and Holocene aeolian activity, palaeostratigraphy and relief evolution in central Poland, [in:] S. Kozarski (ed.), Late Vistulan (Weichselian) and Holocene aeolian phenomena in North and West Europe, Zeitschrift für Geomorphologie Supplementbände 90: 131-142.

Mrózek W., 1958, Wydmy Kotliny Toruńsko-Bydgoskiej [Dunes of the Torun Basin], [in:] R. Galon (ed.) Wydmy śródlądowe Polski, część druga [Les dunes continentales en Pologne, deux partie], PWN, Warszawa: $7-59$.

Niewiarowski W., 1987, Evolution of the lower Vistula valley in the Unisław Basin and at the river gap to the north of Bydgoszcz-Fordon, [in:] L. Starkel (ed.) Evolution of the Vistula river valley during the last 15000 years, p. II, Geogr. Stud., Spec. Issue 4, IGiPZ PAN: 233-252.

Niewiarowski W. \& Noryśkiewicz B., 1983, Some problems concerning the development of the Vistula and Drwęca valley flors in the Torun region, Peterm. Mitteil. Ergänzungsheft, Nr 282, Haack, Gotha: 144-154.

Niewiarowski W. \& Tomczak A., 1969, Morfologia i rozwój rzeźby obszaru miasta Torunia i jego okolic [Morphology and relief development of town area and vicinity of Toruń], Zesz. Nauk. UMK., Geografia 6: 39-89.

Niewiarowski W. \& Weckwerth P., 2006, Geneza i rozwój rzeźby terenu [Genesis and relief development], [in:] L. Andrzejewski, P. Weckwerth, Sz. Burak (eds.) Toruń i jego okolice, monografia przyrodnicza [Torun and its vicinity, natural monograph], Wydawnictwo UMK, Torun: 65-98.

Nowaczyk B., 1986, Wiek wydm, ich cechy granulometryczne i strukturalne a schemat cyrkulacji atmosferycznej w Polsce $\mathrm{w}$ późnym vistulianie i holocenie [The age of dunes, their textural and structural properties against atmospheric circulation patterns of Poland during the Late Vistulian and Holocene], UAM, Seria Geografia 28.

Oczkowski H.L., Przegiętka K.R., Lankauf K.R. \& Szmańda J.B., 2000, Dating of a dune in Kępa Kujawska, Geochronometria 18: 63-68.
Okołowicz W., 1949, Opis geograficzny wydmy Zadroże [The geographical description of the dune Zadroże], [in:] J. Prüffer (ed.) Z badań zespołowych wydmy Zadroże [Collective investigations concerning the Zadroże dune near Toruń], Studia Societatis Scientiarum Torunensis, Supplementum 1: 3-10.

Okołowicz W., 1952, Plejstocen okolicy Torunia [Pleistocene of the environs of Toruń], Biuletyn PIG 66, 2.

van der Hammen T., 1971, The Upper Quaternary stratigraphy of the Dinkel valley (with an annotated list of radiocarbon dates), [in:] T. van der Hammen, T. A. Wijmstra (eds.) The Upper Quaternary of the Dinkel valley, Meded. Rijks Geol. Dienst, N.S. 22: 59-72.

Weckwerth P., 2004, Morfogeneza wybranych obszarów Kotliny Toruńskiej a problem jej roli w układzie hydrograficznym podczas górnego plenivistulianu [Morphogenesis of the selected areas of the Torun Basin and their part in hydrographic network during upper plenivistulian], $\mathrm{PhD}$ thesis, UMK Torun.

Weckwerth P., 2005a, Morfologia i budowa geologiczna teras Kotliny Toruńskiej [The morphology and geological structure of the Torun Basin terraces], [in:] A. Kotarba, K. Krzemień, J. Święchowicz (eds.) VII Zjazd Geomorfologów Polskich, Kraków 19-22 września 2005, Współczesna ewolucja rzeźby Polski [VII Congres of the Association of Polish Geomorphologists, Kraków 19-22 September 2005, Contemporary Poland relief development], Kraków: 501-506.

Weckwerth P., 2005b, Poziomy sandrowe i ich rozwój w Kotlinie Toruńskiej w górnej części plenivistulianu [Outwash levels and its development in the Torun Basin in upper plenivistulian], [in:] A. Kotarba, K. Krzemień, J. Święchowicz (eds.) VII Zjazd Geomorfologów Polskich, Kraków 19-22 września 2005, Współczesna ewolucja rzeźby Polski [VII Congres of the Association of Polish Geomorphologists, Kraków 19-22 September 2005. Contemporary Poland relief development], Kraków: 507-512.

Wojtanowicz, J., 1969, Typy genetyczne wydm Niziny Sandomierskiej [Types of dunes on the Sandomierz Lowland], Ann. UMCS, B 24, I: 1-45.

Wojtanowicz J., 1970, Wydmy Niziny Sandomierskiej w świetle badań granulometrycznych [Dunes of the Sandomierz plain in the light of granulometric examination], Annales UMCS, B, 25: 1-49.

Załuska A., 2008, Studium typów morfologicznych wydm Kotliny Toruńskiej [The study of morphological types of the Torun Basin dunes], Master's thesis, UMK, Torun.

Zeeberg J., 1998, The European sand belt in eastern Europe - and comparison of Late Glacial dune orientation with GCM simulation results, Boreas 27: 127-139. 
